\title{
Extraction of Chitin from Crayfish (Astacus leptodactylus) Shell Waste
}

\begin{tabular}{|c|c|}
\hline Research / Araştırma & \\
\hline $\begin{array}{l}\text { Received / Geliş Tarihi } \\
08.06 .2018\end{array}$ & 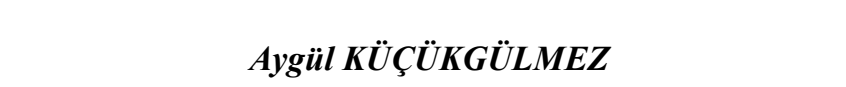 \\
\hline $\begin{array}{l}\text { Accepted / Kabul Tarih } \\
\text { 25.06.2018 }\end{array}$ & $\begin{array}{c}\text { Çukurova University, Faculty of Fisheries, Department of Seafood } \\
\text { Processing Technology, Adana/Turkey }\end{array}$ \\
\hline $\begin{array}{l}\text { DOI } \\
\text { 10.28955/alinterizbd.432139 }\end{array}$ & e-mail:akucukgulmez@cu.edu.tr \\
\hline $\begin{array}{l}\text { ISSN 2564-7814 } \\
e-I S S N 2587-2249\end{array}$ & \\
\hline
\end{tabular}

\begin{abstract}
In this study, chitin was chemically extracted from the crayfish (Astacus leptodactylus) shells. Deproteinization, demineralization and decolorization processes were applied to obtain chitin. In order to determine characterization of the chitosan; yield, moisture and ash contents, degree of deacetylation, colour properties, Fourier Transform Infrared Spectroscopy (FTIR) and Scanning Electron Microscopy (SEM) analyses were applied. The deacetylation degree of chitin from crayfish shells was found as $25.67 \%$ detected by elemental analysis. $L^{*}, a^{*}, b^{*}$, chroma, hue and whiteness in color properties of crayfish chitin were measured. The chemical composition of crayfish chitin was characterized with FTIR analysis. SEM analysis of shells and chitin samples were obtained and compared at different magnification. The findings of the present study are important to obtain the chitin from unevaluated crayfish wastes.
\end{abstract}

Keywords Chitin, Crayfish, Astacus leptodactylus, physicochemical characterization

Please cite this paper as follows / Lütfen aşağıdaki şekilde atıf yapınız:

Küçükgülmez, A., 2018. Extraction of Chitin from Crayfish (Astacus leptodactylus) Shell Waste. Alınteri Journal of Agriculture Sciences, 33(1): 99-104

\section{INTRODUCTION}

Astacus leptodactylus belonging to Astaciadea family is a crustacean species with high economic value, originally from Turkey and has a wide distribution area ranging from Ukraine to Southwestern Russia, Iran, Kazakhstan, Belarus, Slovakia, Bulgaria, Romania and Hungary (Erol et al., 2010). A. leptodactylus, which is, most known as "Turkish crayfish", is a native freshwater crayfish species that can be found in Turkey (Harlığlu, 2004). Nearly $80 \%$ of crayfish comprises wastes (Hunner, 1994). The content of shell in the wastes is $40 \%$ calcium carbonate, $30 \%$ protein and $30 \%$ chitin (Ghannam et al., 2016). Preliminary data show that the crayfish shell, might have peculiar physicochemical properties, possibly providing polymers that are different from, or superior to the obtained from other crustacean wastes (No et al., 1989). Chitin, poly- $[\beta-(1,4)-2$-acetamide-2-deoxy- $\beta$-Dglucopyranose] is the second most abundant polymer after cellulose (Deshpande, 1986). The main difference between cellulose and chitin in terms of their structure is the presence of acetamido group replacing hydroxyl group in the $\mathrm{C} 2$-position in chitin. Chitin has low solubility and reactivity as cellulose. Chitin can be obtained from the cell walls of crab, shrimp, lobster and sea zooplankton, insect cuticle and some fungi (Aspergillus niger and Agaricus bisporus) (Tan et al., 1996; Shiau and Yu, 1999; Rabea et al., 2003; Küçükgülmez et al., 2011). Chemical and biological methods are used in extracting chitin from crustacean wastes. In both methods, the production of chitin from crusts usually consists of three basic stages, being deproteinization, demineralization and decolorization. All of these stages affect the physicochemical properties of the chitin to be obtained.

The number of studies on the properties of chitin is limited although there are a good number of studies on chitosan extraction and characterization in both Turkey and the world. Therefore, this study aims to obtain chitin from crayfish crust wastes separated as waste in Turkey and to determine some properties of chitin.

\section{MATERIALS AND METHODS}

\section{Materials}

Shell materials were obtained from the wastes of crayfish (Astacus leptodactylus). The samples were put in ice to store during transportation to the laboratory. Shells were completely separated from the crayfish samples, washed in pure water and dried at $60^{\circ} \mathrm{C}$.

\section{Chitin preparation}

Chitin from the crayfish shells was extracted by the method of Fernandez-Kim (2004) with some modifications. Deproteinization, demineralization and decolorization process were carried out for chitin extraction, respectively. Deproteinization and demineralization steps were carried out with $3.5 \% \mathrm{NaOH}$ at $65^{\circ} \mathrm{C}$ for $2 \mathrm{~h}$ and $1 \mathrm{~N} \mathrm{HCl}$ at 
room temperature for $7 \mathrm{~h}$, respectively. For decolorization, the chitin residue was treated with $10: 1 \mathrm{H}_{2} \mathrm{O}_{2} / \mathrm{HCl}$ and dried.

\section{Characterization of chitin}

\section{The yield, moisture and ash contents}

The percentage of the yield of chitin was calculated by comparing the weight measurements of the raw material to the chitin obtained after treatment. Yields were calculated as follows:

$$
\text { Yield of chitin }(\%)=(\text { Extracted chitin }(\mathrm{g}) / \text { Crayfish shells }(\mathrm{g})) \times 100
$$

The moisture was determined after drying samples at $103^{\circ} \mathrm{C}$ for $4 \mathrm{~h}$, and ash content was determined by heating at $550^{\circ} \mathrm{C}$ for $20 \mathrm{~h}$.

\section{Determination of the deacetylation degree \\ Elemental analysis}

Eurovector (EA-3000 Single) elemental analysis apparatus was used to determine the amount of C, $\mathrm{H}$ and $\mathrm{N}$ in chitosan. In this case, samples were heated to a temperature of $1000^{\circ} \mathrm{C}$ and approximately $2 \mathrm{mg}$ of chitin was placed inside a silver capsule and dropped into the CHNS-932 furnace, where it was completely combusted. The deacetylation degree was calculated based on the following equations.

$$
D A=\frac{C / N-5.145}{6.861-5.145} \times 100
$$

\section{Colour measurement}

The chitin was put in a transparent petri dish. Colour of chitin was measured using a Hunter lab (Hunter Associates Laboratory, Inc., Reston, VA, USA) which was standardized with a calibration white and black plate. Results were recorded as $L *$ (lightness), $a *$ (redness), $b *$ (yellowness). Chroma, hue and whiteness values of the sample were calculated based on the following equations (Seo et al., 2007).

$$
\begin{aligned}
& \text { Chroma }=\left(a^{* 2}+b^{* 2}\right)^{1 / 2} \\
& \text { Hue }=\operatorname{Arctan}(b * / a *) \\
& \text { Whiteness }=100-\left[\left(100-L^{*}\right)^{2}+a^{* 2}+b^{* 2}\right]^{1 / 2}
\end{aligned}
$$

\section{Fourier Transform Infrared Spectroscopy (FTIR)}

Chitin previously was dried in oven at $90^{\circ} \mathrm{C}$ and the infrared spectrum (IR) characterization was performed in a Bruker Spectrometer (Alpha Platinum, ATR), in the region 3-4000 $\mathrm{cm}^{-1}$.

\section{Scanning Electron Microscopy (SEM)}

The dried chitin was initially coated with Gold-Palladium ( $\mathrm{Au} / \mathrm{Pd}$ ) with automatic coating machine (Cressington Sputter Quater 108 Auto). SEM characterization was carried out using a FEI (Quanta FEG 250 model) type instrument in vacuum environment. Images of the samples surfaces were recorded at different areas and magnifications.

\section{RESULTS AND DISCUSSION}

The yield, moisture, crude ash and deacetylation degree values of the chitin extracted from the crayfish shells are given in Table 1.

Table 1. The physicochemical properties of the chitin extracted from the crayfish shells

\begin{tabular}{ll}
\hline Parameters & $\%$ \\
\hline Yield & $26.44 \pm 2.18$ \\
\hline Moisture & $4.81 \pm 0.62$ \\
\hline Crude ash & $0.86 \pm 0.08$ \\
\hline Deacetylation degree & $25.67 \pm 1.21$ \\
\hline mean \pm standard deviation of triplicate determinations &
\end{tabular}

The yield was calculated for chitin extracted from crayfish. The yield value of chitin was determined as $26.44 \%$. The production stages of chitin are deproteinization, demineralization and decolorization, respectively. In a similar study conducted with crayfish, it was determined that the initial application of the demineralization process in the production of chitin is better in terms of efficiency. It has also been reported that decolorization stage reduces yield (Rout, 2001). Similarly, it has been reported that the yield of crayfish chitin is $25.70 \%$ (Ghannam et al., 2016) and 
16.7-18.8\% (Fernandez-Kim, 2004). Chitin yield was found higher in the results of the present study. This finding results from the different methods, reaction times and temperatures used in the studies. Abdou et al (2008) reported that the chitin content in crayfish ranging about $20-21 \%$ warrants its use as an economic way of producing chitin on an industrial scale.

Moisture and crude ash contents of the chitin are found to be 4.81 and $0.79 \%$ respectively. In a similar study, Rout (2001) reported moisture values in the range of $2.9-5.3 \%$ and ash values in the range of $0.24-0.81 \%$ in crayfish chitin obtained through different methods. Also it was reported that higher moisture $(6.8 \%)$ and crude ash $(4.88 \%)$ values in commercial chitin.

The deacetylation degree is determined by two different methods (titration and elemental analysis). In this study, the deacetylation level was calculated in accordance with the element analysis results. In the element analysis results, $\mathrm{C}$ value was 45.14; $\mathrm{N}$ value was 7.06 and the $\mathrm{H}$ value was 6.39 and the deacidification level was calculated as $25.67 \%$. In fact, deacetylation degree indicates the ratio of the amount of deacetylated N-acetyl-D-glucosamine units to total unit number. The deacetylation value of the chitin at the beginning is very low because deacetylation took place after the chitin extraction had been performed. No et al. (1989) reported a lower level of deacetylation $(7.5 \%)$ in crawfish chitin compared to the present study.

The colour measurements of chitin extracted from crayfish shells are given in Table 2.

Table 2. Colour values of chitin extracted from the crayfish shells

\begin{tabular}{ll}
\hline Parameters & \\
\hline $\boldsymbol{L}^{*}$ & $63.47 \pm 0.42$ \\
\hline $\boldsymbol{a}^{*}$ & $8.35 \pm 1.38$ \\
\hline $\boldsymbol{b}^{*}$ & $16.44 \pm 1.54$ \\
\hline Chroma & $18.45 \pm 1.95$ \\
\hline Hue & $1.10 \pm 0.04$ \\
\hline Whiteness & $59.15 \pm 1.46$ \\
\hline mean \pm standard deviation of triplicate determinations
\end{tabular}

In colour measurements, chroma, hue and whiteness values were calculated in addition to $L^{*}$ (lightness), $a^{*}$ (redness) and $b^{*}$ (yellowness) values. In the present study, high $a^{*}$ and $b^{*}$ values were detected. In a similar study, the $L^{*}$ value of the crayfish chitin obtained by different methods was reported between 44-64.8; $a^{*}$ value between 1.9-8.2, $b^{*}$ value between 4.6-9.4, chroma value between 6.8-11.1 and hue value between 31.6-76.8 (Rout, 2001). In addition, the same author found that the colour values of commercial chitin obtained crab were similar to the present study. Yen et al. (2009) reported similar $L^{*}(62.4), b^{*}(14.7)$ and whiteness (59.6) values in purified crab chitin. The most important parameters in the formation of color are shell source and decolorization method.

Figure 1 presents the FTIR spectrums of the chitin extracted from crayfish shells. To detect the chitin structure, Fourier Transform Infrared (FTIR) spectroscopy was applied. 


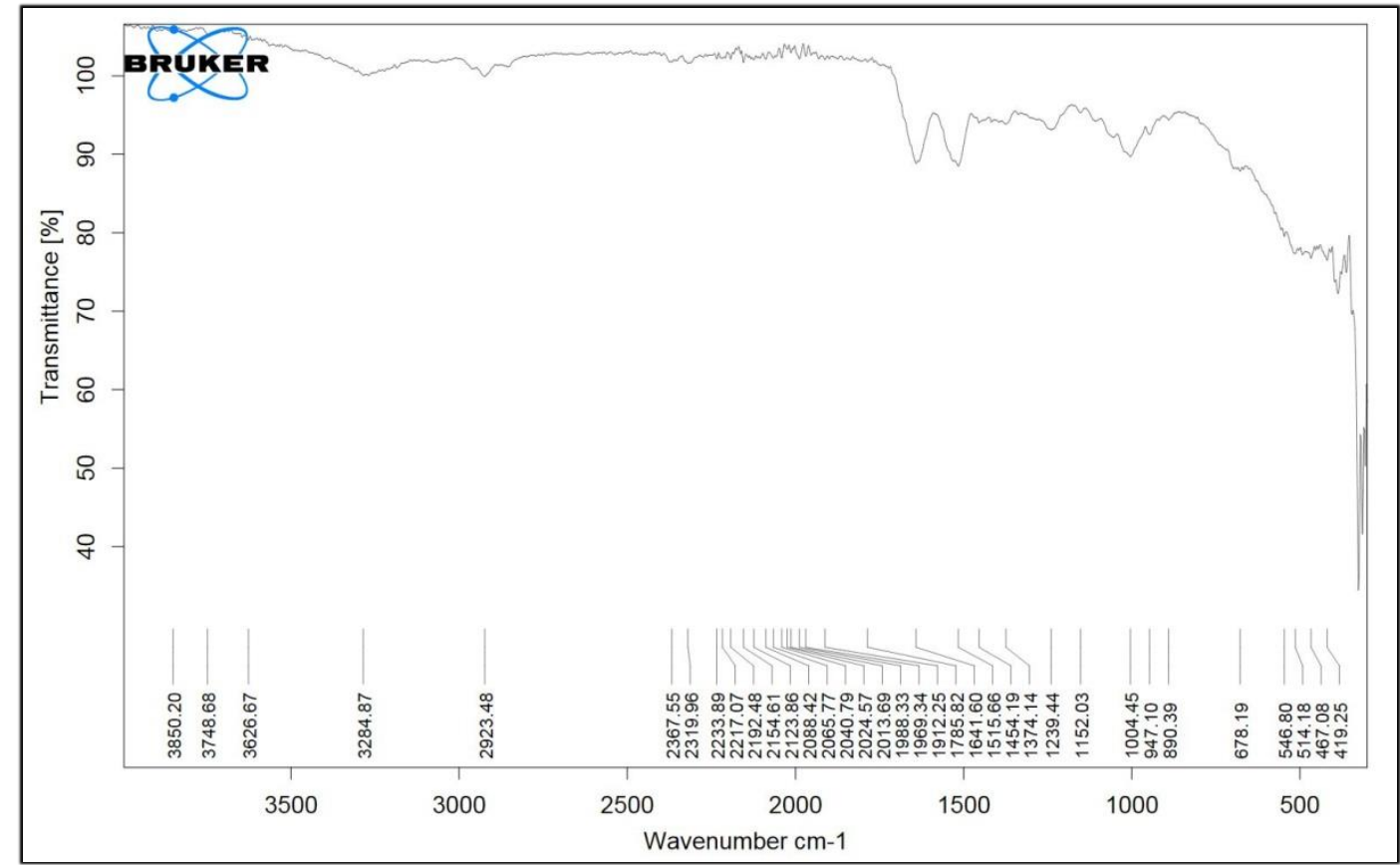

Figure 1. FTIR of chitin extracted crayfish shells

According to FTIR analysis of the chitin obtained from crayfish shells, the peaks between $400 \mathrm{~cm}^{-1}$ and $678 \mathrm{~cm}^{-1}$ are called "fingerprint peaks". The bonds representing the $\mathrm{C} 2$-position $(\mathrm{C}=\mathrm{O})$ of the glucosamines from the main groups of the compound were found at $1004 \mathrm{~cm}^{-1}$. Absorbance peaks representing $\mathrm{C}-\mathrm{O}-\mathrm{C}$ bonds with ring structure were found at $1152 \mathrm{~cm}^{-1}$; absorbance peaks of the $\mathrm{C}_{-} \mathrm{CH}_{3}$ and $\mathrm{CH}_{2}$ groups were at $1374 \mathrm{~cm}^{-1}$; absorbance peaks indicated as stretching vibration peak in $\mathrm{CH}_{2}$ group were at $1454 \mathrm{~cm}^{-1}$; peaks of $\mathrm{C}=\mathrm{O}-\mathrm{C}-\mathrm{N}$ bonds were at 1515 $\mathrm{cm}^{-1}$. In addition, peaks belonging to $\mathrm{OH}$ bonds belonging to hydroxyl groups between $2923 \mathrm{~cm}^{-1}$ and $3300 \mathrm{~cm}^{-1}$ were detected.

The SEM images of crayfish shells and chitin with various magnifications are presented in Figure 2 and Figure 3.
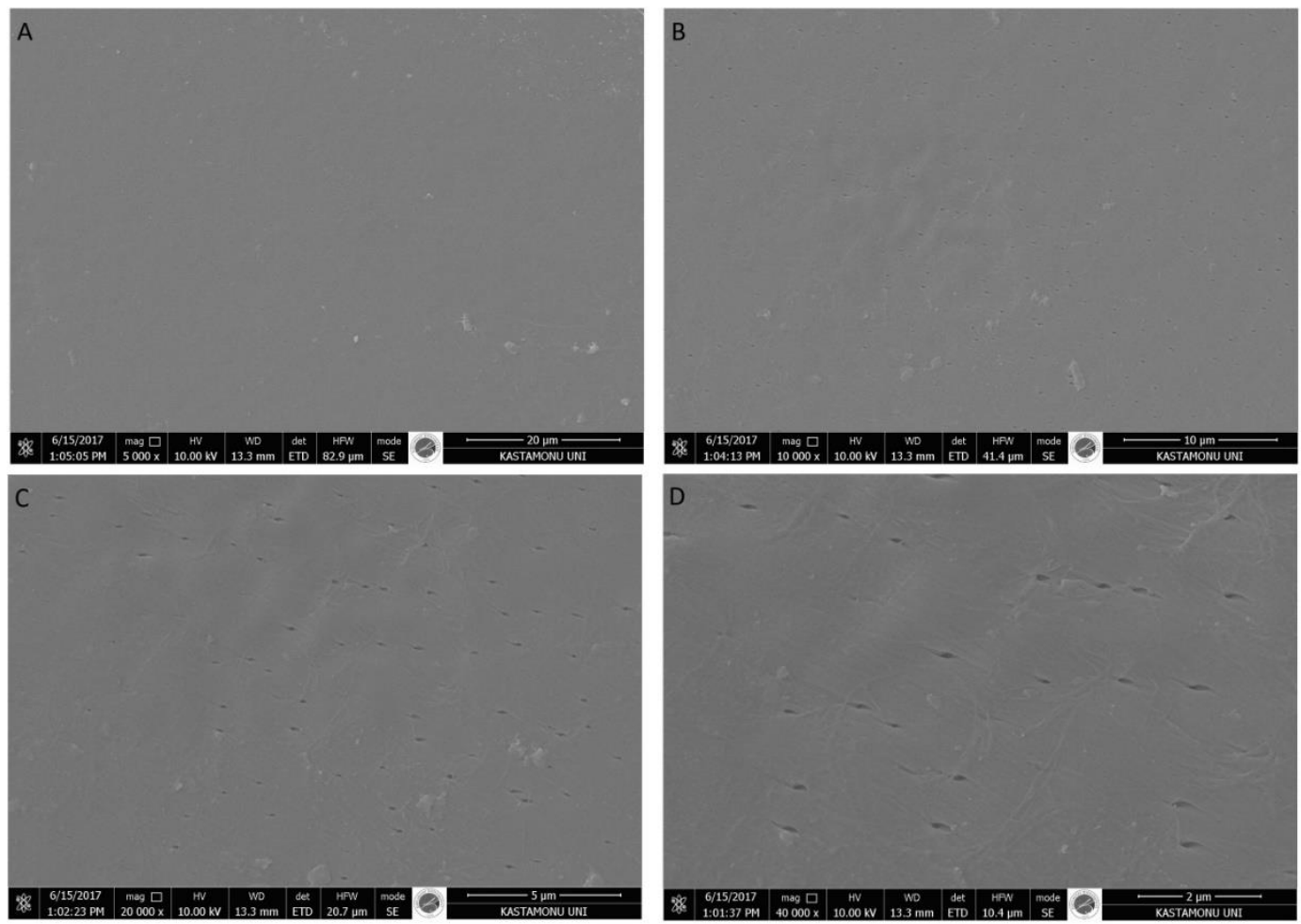

Figure 2. SEM images of crayfish shells (A: 5000x, B: 10000x, C: 20000x, D: 40000x) 

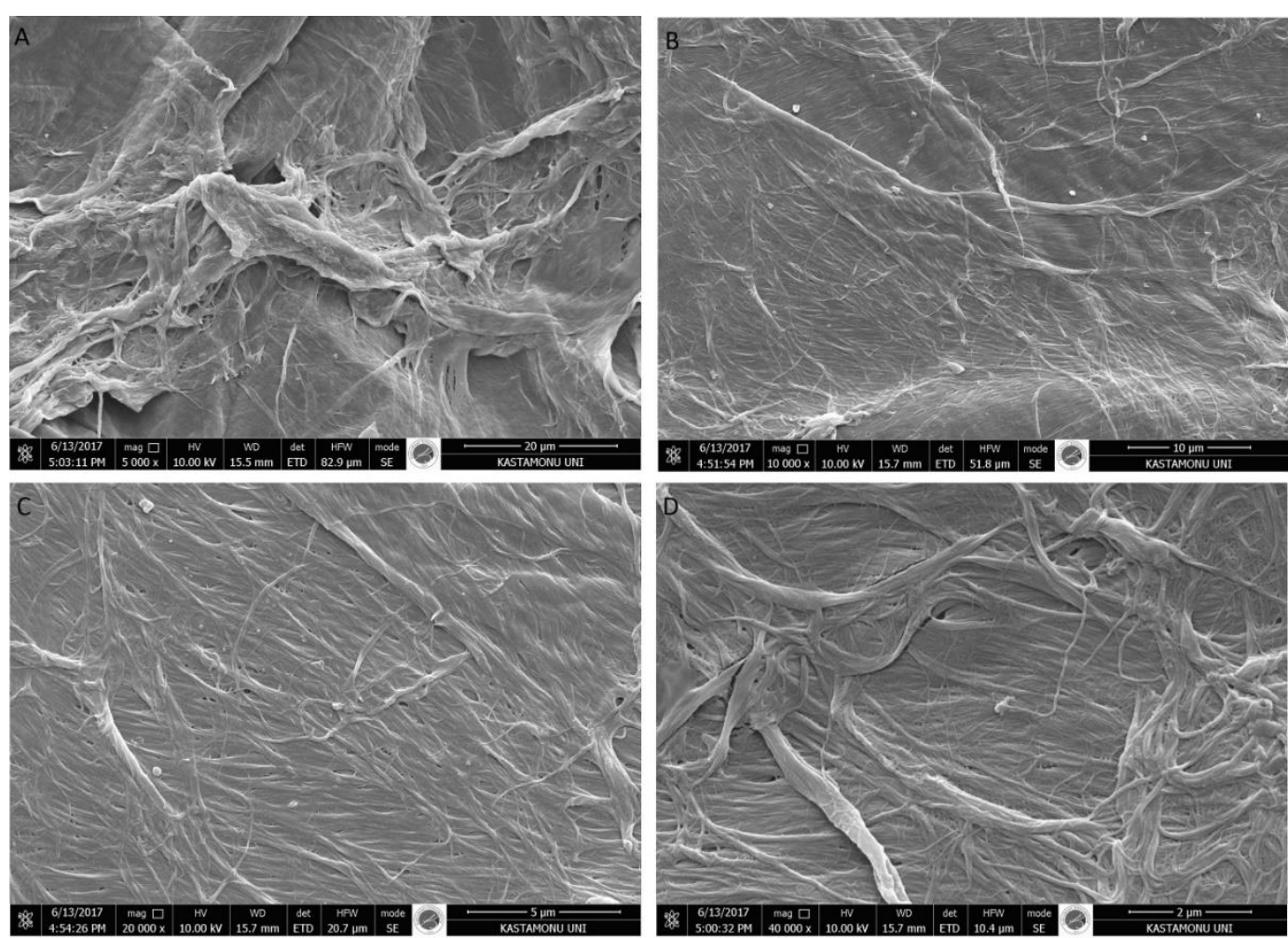

Figure 3. SEM images of chitin extracted from crayfish shells (A: 5000x, B: 10000x, C: 20000x, D: 40000x)

SEM analysis gives information about the surface structure of the material (roughness, homogeneity, folds, layer and pore structure). In this study, images of chitin with different magnification values such as 5000x, 10000x, 20000x and 40000x were obtained after the chitin was obtained at the end of demineralization, deproteinization and decolorization processes prior to the processing crayfish shells. When the obtained images are morphologically evaluated, it can be seen that the surface of the crude shell material is perforated and has a smoother structure. As presented in Figure 2, it is seen that the protein, minerals and colouring materials within the body of the crude shell material cover the filamentous structure seen in chitin and therefore, there is a smooth structure. As presented in Figure 3, this filamentous structure is clearly seen with the removal of the protein, minerals and colouring substances in the chitin material.

\section{CONCLUSION}

This study examined the extraction of chitin from crayfish (A. leptodactylus) shell wastes. It was found that crayfish could be a commercial source of chitin. With the advancement of shellfish processing technology, the evaluation of crustacean waste has become a very important issue. Crustal wastes, which cannot be assessed in the aquaculture processing factories in Turkey, have great potential. The assessment of these wastes is a very important issue for both the aquaculture and other industries. While there are many international studies on crayfish and other crustacean wastes to be assessed in different fields and used to bring an economic income, the number of studies related to the subject is limited in Turkey. To this end, the present study, which focuses on crayfish shell wastes separated as wastes in Turkey, will be a pioneer for many other crustacean wastes for chitin extraction and determination of some properties.

\section{REFERENCES}

Abdou, E.S., Nagy, K.S.A. and Elsabee, M.Z., 2008. Extraction and characterization of chitin and chitosan from local sources. Bioresource Technology, 99:1359-1367.

Deshpande, M.V., 1986. Enzymatic degradation of chitin and its biological applications. Journal of Scientific \& Industrial Research, 45:273-281.

Erol, G., Özkök, R., Küçükkara, R., Çınar, Ş., 2010. Tatlı Su İstakozu Astacus leptodactylus (Eschscholtz, 1823) Yetiştiriciliğinde Yavru Dönemde Muhtemel Ölüm Nedenleri. Süleyman Demirel Üniversitesi Eğirdir Su Ürünleri Fakültesi Dergisi, 6(2): 23-30.

Fernandez-Kim, S.O., 2004. Physicochemical and Functional Properties of Crawfish Chitosan as Affected By Different Processing Protocols. Master Thesis. Louisiana State University and Agricultural and Mechanical College.

Ghannam, H.E., Stalab, A., Dolgano, N.V., Husse, A. and Abdelmagui, N.M., 2016. Characterization of Chitosan Extracted from Different Crustacean Shell Wastes. Journal of Applied Sciences 16:454-461. 
Harlığlu, M.M., 2004. The present situation of freshwater crayfish, Astacus leptodactylus (Eschscholtz, 1823) in Turkey. Aquaculture, 230: 181-187.

Hunner, J.V., 1994. Freshwater Crayfish Aquaculture in North America, Europe, and Australia Families Astacidae, Cambaridae, and Parastacidae. Food Products Press, An Imprint of the Haworth Press, Inc. New York, London.

Küçükgülmez, A., Celik, M., Yanar, Y., Şen, D., Polat, H. and Kadak, A.E., 2011. Physicochemical characterization of chitosan extracted from Metapenaeus stebbingi shells. Food Chemistry, 126:1144-1148.

No, H.K., Meyers, S.P. and Lee, K.S., 1989. Isolation and Characterization of Chitin from Crawfish Shell Waste. Journal of Agricultural and Food Chemistry, 37(3):575-579.

Rabea, E.I., Badawy, M.E.T., Stevens, C.V., Smagghe, G. and Steurbaut, W., 2003. Chitosan as antimicrobial agent: applications and mode of action. Biomacromolecules, 4(6): 1457-1465.

Rout, S.K., 2001. Pyhsicochemical, functional, and spectroscopic analysis of crawfish chitin and chitosan as affected by process modification. M.S. in E.S., Louisiana State University.

Seo, S., King, J. M. and Prinyawiwatkul, W. 2007. Simultaneous depolymerisation and decolorization of chitosan by ozone treatment. Journal of Food Science, 72(9), 522-526.

Shiau, S.Y. and Yu, Y.P. (1999). Dietary supplementation of chitin and chitosan depresses growth in tilapia, Oreochromis niloticus O. aureus. Aquaculture, 179:439-446.

Tan, S. C., Tan, T. K., Wong, S. M. and Khor, E., 1996. The chitosan yield of zygomycetes at their optimum harvesting time. Carbohydrate Polymers, 30(4): 239-242.

Yen, M.T., Yang, J.H. and Mau, J.L., 2009. Physicochemical characterization of chitin and chitosan from crab shells. Carbohydrate Polymers, 75:15-21. 